\title{
CITIES TOWARDS GLOBAL CLIMATE GOVERNANCE: HOW THE PRACTICES OF CITY DIPLOMACY FOSTER HYBRID MULTILATERALISM ${ }^{1}$
}

\section{INTRODUCTION}

Global complexity is an opening for the vertical disintegration of foreign policymaking. A central government faces enormous pressure on international policy-making and problem-solving where actors from the subnational level raise their voices (Wang, 2006; Barber, 2013). The ongoing process of globalization facilitates the involvement of other actors who grasp the opportunity to contribute to the global agenda (Castells, 2005; Kuznetsov, 2015), integrates international society and reduces the salience of borders; therefore, cities are recognized as internationally important centres of political and economic power (Sassen, 2001; Acuto, 2010; Curtis, 2014; Rapoport, Acuto, Grcheva, 2019; Amiri, Sevin, 2020). These new actors' engagement creates a new form of global diplomacy, especially throughout transnational networks, and shapes a parallel to the traditional Westphalian system (Acuto, 2017; van der Pluijm, 2017; Oosterlynck et al., 2019).

The paradox of the internationalization of nation-state foreign policy, which has local implications, already appears in the literature (Hocking, 1993; Keating, 1999; Sassen, 2004). The world scene has fragmented, and the spatiality has begun to lose its importance, which some scholars refer to as a crisis of the nation-state concept (Keohane, Nye, 1974; Giddens, 2000). Besides, the activism of city diplomacy is not carried out exclusively by federal states or established democracies (Cornago, 2010: 17). It is argued that city diplomacy is the result of the decentralization of international relations, where states cease to represent the only strong political entities, and cities represented by mayors increase their activity at the international level (Van der Pluijm, 2007: 11; Curtis, 2014: 135; Tavares, 2016). In this context, cities have become significant players in international relations in recent years. However, the question remains: how do we frame cities' autonomous activities in the global governance agenda?

1 This article was created within the IGA Grant Competition project "The Challenge of Integration and Disintegration Tendencies and Processes Within Different Levels of Governance" n. F2/48/2020. 
The multi-actorness in global governance has recently attracted the attention of many scholars, which was particularly evident at the United Nations Framework Convention on Climate Change (UNFCCC) conferences. The steppingstone for the scholars was the evolvement of less hierarchic institutional interaction, which occurred during the climate governance arrangements (Betsill, Bulkeley, 2006; Bäckstrand, 2008; Andonova, Betsill, Bulkeley, 2009; Newell, Pattberg, 2012). Simultaneously the multilevel governance was adopted as a framework even though it had been mostly used as a descriptive tool for the European decision-making levels (Hooghe, Marks, 2001); however, "multilevel governance" is currently a widely accepted term for various contacts among different actors from the governing scale. According to the abovementioned authors, the less hierarchical code of conduct thus legitimizes some of the autonomous activities.

The Paris Agreement brought about a momentum for the non-state actors and for the cities as well. The growing recognition of transnational city networks by national governments scale up their opportunities to cope with climate change (Bäckstrand et al., 2017). In this context, hybrid multilateralism, defined as cooperation among different actors at different levels, provides links to multilateral negotiations and, together with orchestration, represents a means to harness multiple actors' disparate activities toward common goals (Dryzek, 2017: 3). Through this linkage, subnational actors demonstrate their crucial potential to address global issues (e.g., reducing GHG emissions) and direct contribution to the fulfilment of the central governments' climate governance commitments. Furthermore, as Bäckstrand et al. define it, the concept of hybrid multilateralism is a "heuristic to capture this intensified interplay between state and non-state actors in the new landscape of international climate cooperation" (2017: 562).

Yet, the dichotomic position, especially of cities, is still under discussion. City leaders are often asked to assume the executive role in adopted climate measures. At the same time, their position is not precisely conceptualized and framed in climate governance, and the same situation occurs within the nation-state. In other words, "non-state actors are asked to cooperate with states to ensure best practice on monitoring emission reductions; on the other, non-state actors are themselves asked to reduce their emissions through voluntary commitments framed as complementary to state action" (Bäckstrand et al., 2017: 13).

This article examines mostly neglected contradictory actions of cities pledging the international climate commitments. Are the cities powerless regarding the contradictory position with the central government, or do the hybrid arrangements push cities to act unilaterally against climate change? In order to identify cities' diplomatic practices through which they enter the international environment under non-traditional channels, we observe their connection to global climate challenges after the withdrawal of President Trump administration from the Paris Agreement. We then analysed the dynamics of the major pledges to better understand the climate arrangements' hybrid structure.

The first section gives an overview of the city diplomacy position in the IR theories. The second chapter links hybrid multilateralism to the cities' initiatives underlying the specificity of the international climate arrangements. Finally, in the third section, we 
analyse the practices which bind the cities to deliver the results from the commitments through the pledges as a type of international interaction.

Firstly, research into cities' practices in the framework of hybrid multilateralism helps uncover their global governance potential. Secondly, the essence of the further debate is to reveal whether cities' diplomatic practices form new norms in global climate governance under the hybrid architecture.

\section{THE CITY DIPLOMACY PRACTICES THEORIZED}

City diplomacy and its reflection in international relations theory could be considered as a new trend among scholars. From the constructivists' position, the diplomacy of sub-state units results from intersubjectivity, which shapes international relations. The situational standpoint of individual actors is determined by social constructions designed based on their interactions with other actors around the world. Thus, in contrast to the two grand theories, in this case, the opposite development occurs, namely a development from the bottom up (Wendt, 1992). City diplomacy is perceived here as an effort to build ones' own identity. Cities can consequently reimagine their positions in globalisation.

According to constructivists, international actors' position in the global political system cannot be generalized because it is determined by social constructions that are created based on their interactions with other actors. However, without context, actors lack the meaning given to them by social values and norms, among other things. Social reality is objectified by human interactions, which gradually become a pattern. Such repetitive patterns are institutionalized and shifted to a generally perceived reality and objective knowledge (Pouliot, Cornut, 2004; Bueger, Gadinger, 2018). Still, this process is also influenced by the subjective creation of individual identities within each individual and comes from the social space in which we interact (Utomo, 2019). Based on the theses of Michel Foucault, who rejects the perception of power as a result of the behaviour of one power centre but sees power as encompassing various state and non-state actors whose used tools, required knowledge, and emotions create practices that constitute a broader phenomenon of how cities engage in todays' international relations. Thanks to the approach of social constructivism, it will be possible to examine the role of cities through the processes of their interaction and, at the same time, monitor patterns of their behaviour in the international environment from the perspective of diplomatic practices.

The speeding up of the globalization processes creates a new global society with a global consciousness and a global ethic which "is being forced upon this generation by new technological, ecological, and political realities" (Kirby et al., 1995). Cities, as they become more and more involved in the global agenda and represent a significant part of civil society, tremble nation-state, especially regarding the climate crisis (Betsill, Bulkeley, 2006). Cities impose limitations on nation-states by creating moral imperatives through the behaviour of their representatives. Signalling this behaviour with their diplomatic practices, mostly through transnational platforms and networks, they generate a shared global morality, in other words, "the assertion of universal norms 
motivating activism that results in the formation of network structures which enable subnational actors to mobilize resources to collectively create pressure on the national government" (Leffel, 2018: 3).

Recently, more attention has been focused on the constitutive effects of diplomatic practices as meaningful social patterns (Neumann, 2012) on various areas of the global political system. What the actors do and how they do things create world politics (Pouliot, Cornut, 2004). Bouteligier (2013) carefully summarized that norms, values, and practices of governance could be produced and reproduced through city networks and their collective action, capacity, and meaningful effect. According to the theory of world society, norms and practices are disseminated through transnational organizations (Meyer, 2010). If the nation-state does not implement these norms and practices, and central governments violate or fail to enforce them, the subnational actors will independently take over (Shuman, 1986; Adger et al., 2009; Leffel, 2018). Cities, by their actions, often express the values of society. The increased activity of the cities following the withdrawal of President Trump administration from the Paris Agreement has led many of them to undertake a range of specific actions to clarify their position toward and preparedness for the fight against climate change. This stand-alone city demonstration resembles the Nuclear-Weapon-Free Zones (NWFZ) initiative, which began at the level of city mayors and, with significant diplomatic pressure, managed to put the issue on the international table (Leffel, 2018).

Examining city diplomacy, we cannot neglect that city diplomacy strategies are strongly influenced by the mayors' local contexts and political mindsets and their positions in the international environment where the global agenda is dealt with (Barber, 2013). Barber further argues that today state sovereignty is a handicap in managing the global agenda and that cities are better prepared to respond to global challenges. He believes that cities are an ideal choice for overcoming nationality and sovereignty barriers and moving towards a cosmopolitan society. However, most of the city actions are often characterized uncritically and without considering whether these actions affect international politics or policy in any substantial capacity.

In the literature, we repeatedly find the perception of more intense subnational diplomacy as a consequence of continuous neglecting by the central government (Hocking, 1993, Keating, 1999; Criekemans, 2010; Cornago, 2010). Although, earlier diplomacy on the sub-national level was perceived as conflicting only when sub-national governments put in place initiatives and activities through which they aspired to establish themselves as governments of fully sovereign states (Aldecoa, Keating, 1999: 3; Tavares, 2016: 48). This secessionist presumption may apply to regions but not to cities, for which the territory is not one of the most critical characteristics.

Relating to the legitimacy according to the second Nuremberg Principle, "the fact that internal law does not impose a penalty for an act which constitutes a crime under international law does not relieve the person who committed the act from responsibility under international law." Cities, therefore, may feel compelled to act and help enunciate, develop, and codify international norms that can be the basis for effective international law (Shuman 1988: 2-4) and believe they have a duty to adhere to international norms and laws. Failure to comply with obligations stemming from international climate agreements can without a doubt lead to a discrepancy between the 
central government and the city. Non-recognition of the problem and non-compliance with international standards by the central government strengthen the subnational actors' related activities (Acuto, 2013; Leffel, 2018).

Todays' global connectivity helps in the sharing of norms and increases the power of local actors and processes in initiating global interests and collective goals (Betsill, Bulkeley, 2006). Globalization brings about a reconfiguration of territoriality and sovereignty and the role of cities in making foreign policies (Curtis, 2016). City diplomacy is much more flexible and less ceremonial and symbolic than traditional diplomacy; nevertheless, the decisions made on the local level differ from those adopted on a national level in terms of proximity and the speed of their impact (Tavares, 2016: 116-118).

Understanding cities' policy-oriented or functionality-driven practices and how actors grasp and act in these specific situations allows for encompassing the whole process of involvement of cities in global climate governance (Hickmann, 2015). According to Kern (2019) global climate governance has always been multilevel in structure. Furthermore, other scholars put the city networks on the front of the battle with climate change (Lee, 2013; Acuto, Rayner, 2016), and it is conclusive when quantifying climate change contributors. Cities consume over 67 per cent of the worlds' energy and emit 70 per cent of their carbon dioxide emissions (C40 cities, 2018); therefore, cities were substantially motivated within the sustainable development process since the Rio Summit in 1992 (ARUP report, 2011). This could be repeatedly observed during the Earth Summit in Johannesburg in 2002, where cities' representatives presented their vision in the Local Governments' Declaration (Tavares, 2016: 126). However, we can have doubts as to how seriously these initiatives were perceived.

The rising voices and the abundance of multilateral partnerships, which could not be overlooked, emerged significantly after the failure of the central governments to comply with the international commitments. Cities are then undertaking the vindication of commitments which they perceive as crucial for the international climate regime. The most obvious cases of this come from the US: when in 2001 President George W. Bush declared that the United States would not ratify the Kyoto Protocol (Kuyper et al., 2017) and, as already mentioned, the withdrawal of President Trump administration from the Paris Agreement. These voluntary pledges and initiatives have contributed to the evolvement of another international negotiations' architecture and form a parallel to the inadequate multilateral action (Jordan et al., 2015).

\section{HYBRID MULTILATERALISM AS A NICHE FOR CITIES}

Prevailing system of global governance still revolves around territorial sovereignty and transnational economic ties. Nonetheless, we are encountering a fusion of public and private actors coming together in hybrid functional networks to find solutions to problems of collective action; as Curtis (2016) delineates, "these are forms of interaction that are horizontal, non-hierarchical, and embrace the bottom-up dynamics of self-organization. The normative proposition is that they bypass vertical, hierarchical, and centralized (statist) structures where power has so often ossified in the history 
of the 21st century" (2016: 9). The international meetings provide a playground for these interactions through their negotiations' battlefield. The UNFCCC is one of the vital multilateral conventions addressing climate change and the limitation of global warming; it was signed in June 1992 at the UN Conference on Environment and Development in Rio de Janeiro. This assemblage annually brings together UN member states at the Parties Conference (COP) to advance the agenda for global climate change mitigation, adaptation, and resilience.

The emerging debate about the extension of competencies in the vertical direction was already observed during the negotiations on the Kyoto Protocol. Then, the global climate governance slowly took a course to the changes of the interplay among parties (Dryzek, 2017: 1). The 2009 COP 15 in Copenhagen is described by Bäckstrand and Lövbrand (2015) as a turning point for global climate politics. The rise of numerous kinds of climate governance arrangements unfolded from the bottom up and exceeding the framework of international climate conferences; they have pointed to the hybrid architecture of global climate governance (Betsill, Bulkeley, 2006; Toly, 2008; Bäckstrand, 2008). Bäckstrand et al. (2017) refer to this progress as hybrid multilateralism and connect it with the attempt to link established multilateral negotiations led by supranational institutions with the non-state actors' actions while not excluding the central governments. However, it is not yet well described which of these links in the intriguing area of the multilevel international climate regime we can include discussing cities.

A different governance structure that goes beyond the UNFCCC framework sprang up from special events and platforms involving many types of actors and actions. Still, hybrid multilateralism represents guidance on how this cooperation, where states and other non-traditional, self-organizing governing bodies work together and develop a parallel to global governance architecture that bypasses traditional hierarchical channels, should function (Bäckstrand, 2017).

Following the UNs' obvious goal concerning cities - to enrol them in the climate change battlefield, especially at a time when the Paris Agreement on Climate Change had not carried through its commitments and the COP25 Climate Conference, which took place in December 2019 in Madrid, had not moved forward, we can discern the multiplication of hybrid initiatives such as, e.g., the current Race to Zero global campaign. The climate crisis challenges a unilateralist approach to address its global impacts. Climate change, ocean and air pollution, nuclear risk, biodiversity loss, all these aspects of the climate crisis put pressure on streamlining global governance, which involves significantly more actors than merely states. Environmental policy and how it is discussed, specifically the rhetoric accepted by the representatives at all levels, conceive a meaning and influence the discourse around climate change (Dryzek, 2017: 8).

When discussing the period before the Paris Agreement, which means the period prior to 2015, the discourse spun mainly around whether subnational actors would be involved in the climate agenda, while prevailing debate examines the practices and conditions under which subnational actors contribute to global climate governance (Bäckstrand, 2017). The Paris Agreement brought about a multilateral contract that encompasses subnational actors in the field of transnational governance in the process 
of its creation (Dryzek, 2017). However, the failure of the negotiated Paris Agreement was already indicated in 2017 by the withdrawal of the US. It revealed that central governments' policy goals might differ significantly from those formulated by cities; although, cities' impact on the environment can be decisive (Lecour, 2002).

As far as the adoption of the Paris Agreement is voluntary, the US withdrawal was perceived as a symbolic action towards the potential voters in President Trumps' second presidential campaign, yet still as a significant step backwards in the effort to mitigate climate change (Leffel, 2017). The US abdicating its leadership on climate change was comprehended as a suggestive action from the central government. We can put on the table the question to what extent this was simply a populistic and yet rhetorical step that President Trump used to appeal to the strong industrial past of the US and arouse nostalgia in the people, even though a report from the Ember (Graham, 2021), an independent climate think-tank focusing on the global electricity transition, reveals data that show a continuing decline in coal use and a growing share of renewables in electricity consumption.

The most prosperous sub-national entity in the world, the government of California, previously engaged in the climate agenda as a direct result of its global leadership in reducing air pollution. The Chinese government properly recognized California's authority on climate issues, and thus the governor of California, Jerry Brown, met with China's environmental protection minister, Zhou Shengxian, in Beijing in 2013 to discuss and sign a non-binding agreement to reduce smog and greenhouse gas emissions. During the trip, China also requested the help of the experts at the California Air Resources Board to address its urgent air pollution problem, which likewise paved the way for the hybrid multilateral paradigm. Another agreement signed in September 2013 by California and Québec to link their carbon emissions allows them to regulate emitters in both regions and to buy and sell carbon emissions allowances and offsets in either jurisdiction. These initiatives, on the other hand, are also used as channels to communicate, inspire and recruit more participants to fill the federal leadership gap (Tavares, 2016: 37).

Some could argue that these initiatives can be seen only in strong federative Western democracies. Yet, in December 2019, the progressive capital cities of Slovakia, Hungary, the Czech Republic, and Poland, whose central governments oppose European Union policies on immigration and climate change, came together to create the "Pact of Free Cities" (Foreign Policy, 2020). The message from the mayors was clear and signalled they are sticking to the international commitment, even though it did not correspond to the central governments' positions. While no two cities are the same, city diplomacy is coalescing around shared values such as partnership, cooperation, and inclusion (Acuto, 2017). In other words, cities are gaining more "soft power" on the international stage, even as they remain structurally powerless in the international system of governance (Acuto, 2017). The impact of cities on climate change is the best demonstration of a linkage between local and global that can go beyond the central governments' potential (Hale, 2018). Cities have begun to assert themselves and make their voices heard, and in cases such as the New Urban Agenda adopted at the United Nations Conference on Housing and Sustainable Urban Development (Habitat III), they actually participate in the initial stage of the agenda-setting. 


\section{HYBRID PRACTICES OF CITIES}

The transition to a zero-carbon economy has begun in almost every market in the world. Despite the previous lack of leadership on climate change from the White House, a growing number of American cities and companies (some of them representing the American dream - e.g., Hewlett Packard Enterprises, Levi Strauss \& Co.) have connected in the growing movement "We Are Still In," intending to stick with the principles of the Paris Agreement. This initiative has evolved into "America Still In," which is composed of 3,800 leaders across the 50 states of America, crosssectionally putting together a significant amount of the US economy in the pursuit of climate action.

Non-recognition of the problem and non-compliance with international commitments and regulations by central governments leads to a strengthening of subnational actors' related activities. These practices of cities foster their position in the global environment and enable the establishment of contacts that would otherwise be impossible for the government. Such connections can lead to a level of cooperation which national governments would never reach, as seen in California's collaboration with the Belt and Road Initiative representatives. This bypassing of the central government strengthens the hybrid multilateralism, which allowed for mitigating the implications of the US withdrawal from the Paris Climate Agreement.

The US Climate Alliance with over 250 cities has pledged to enforce the Paris Agreement, thus opposing the US national government. Furthermore, the members are committed to implementing policies that advance the Paris Agreements' goals, straightforwardly aiming to reduce GHG. On June 2, 2017 (just one day after President Trumps' announcement), Mayor de Blasio signed Executive Order 26, thus committing New York City to the Paris Agreements' principles. Specifically, New York has committed itself to help keep the global temperature rise below 1.5 degrees Celsius. During Michael Bloombergs' administration (2002 to 2013), the city showed tremendous leadership in foreign affairs, mainly through the major city network for climate change C40. Still, the flame somehow faded away when he stepped down.

The personalities of decision-makers can strongly influence the determination of subnational governments' international policies. For example, statistical research conducted on the rationales that lead US governors to conduct foreign affairs indicates that governors' personal interests seem to drive their involvement in international activities (McMillan, 2008: 242). Likewise, city diplomacy strategies are strongly influenced by the local contexts, mayors' political mindsets and their positions in the international environment (Barber, 2013). However, these circumstances blur when it comes to the hybrid arrangements.

The current Race to Zero global campaign run by the COP26 Presidency and High-Level Climate Champions highlights the cooperation through the different governance levels. The Cities Race to Zero effort emphasises the implementation of inclusive and resilient climate action ahead of the COP26 in Glasgow through the support of the prominent city networks (e.g., C40 Cities, the Global Covenant of Mayors, ICLEI - Local Governments for Sustainability, UCLG - United Cities and Local Governments). 
The growing engagement in the global initiative, which goes outside national governments, is mediated mainly through online platforms and social media. For instance, hashtag \#racetozero is constantly used by the UNFCC representatives, city officials, ministries of countries, corporates and even individuals to further promote the objectives that aim to just and resilient zero-carbon recovery. The rising participation in this global call is undeniable. Lastly, five important Indian cities (Mumbai, Pune, Aurangabad, Nagpur and Nashik) pledged their commitments.

The ambitious goals and pledges are often critiqued for their merely rhetoric function. Hence, as Bäckstrand et al. (2017) brought up, participation does not necessarily enhance effectiveness in climate change combat. Tackling evaluating, monitoring and compliance, the Carbon Disclosure Project (CDP), a not-for-profit organisation, developed a system that provides data to UNs' Global Climate Action Portal has strengthened data disclosure of cities as one of the crucial steps to climate action leadership. Cities are included on the CDPs' Cities A List which serves as a building block for further promoting the best practices and lessons learned. Together with ICLEI, they developed a CDP-ICLEI Unified Reporting System which the UNFCC supports.

According to Hickmann, the emergence of such a great variety of different climate governance arrangements beyond the international climate regime has led to a significant increase in the institutional complexity of global climate governance (2015: 5). Given that the hybrid multilateralism, institutionalised through the Paris Agreement (Bäckstrand et al., 2017), enables expanding the 'multi-level and multi-arena nature of climate governance' (Bulkeley, Newell, 2010: 13), we emphasise the informal channels used to pledge to undertake not merely international agreements' commitments but also expose the ambitions that are significantly important for cities' international involvement. Furthermore, these informal channels interlinks allow encompassing cities and businesses of smaller scale and even individuals. However, the impact of the aggregation of bottom-up pledges, supranational commitments, and states nationally determined contributions (NDCs) is yet still behind to uncover.

As Bäckstrand et al. (2017) correctly pointed out, "the hybrid arrangements raise questions about the critical capacity of non-state actors to hold states and intergovernmental actors to account for their (in)actions." We argue that cities are taking on the role of intermediaries of international goals when they are aware of the inadequacy of the central governments' action using informal channels to promote and justify their commitments. Since we do not follow the complementary relationship assumption, the cities' conflict position forces them to carry out their own autonomous activities, fosters their international identity through hybrid multilateralism-though, the collaboration of existing modes of operation thrown up many questions in need of further investigation.

$* * *$

Through city diplomacy, local activism has a global impact. This considerable rise of cities' initiatives in recent decades has resulted in the growing number of informal arrangements that emphasize the multilateral hybrid structure of the international climate regime. Even with these apparent trends, though, states remain reluctant to cede 
power over fiscal matters and specific policy decisions; however, the less hierarchical code of conduct, evolving from the bottom-up participation in climate change governance, legitimizes some of the autonomous activities relating specially to reducing greenhouse gases, climate change mitigation, and decarbonization.

According to our research, the inadequacy of the central governments' action to fulfil the international commitments speed up the cities' involvement in the international climate change agenda and nurture the emerging phenomenon of hybrid multilateralism. At the same time, hybrid multilateralism unlocks cities the possibilities of international exposure. Our analysis highlighted the informal channels as critical for the cities to share common interests, act unilaterally against climate change, and follow the responsibilities steam from the international climate arrangements.

Considering the cities' actorness in global environmental governance, the question remains, whether the climate change governance would more benefit from the coherence and continuity within the national level or contrary. Still, city diplomacy could be an opportunity for central governments to remain international as the growing quantity of transnational ties could be beyond the central governments' capacity to attend.

\section{REFERENCES}

Acuto M. (2013), Global Cities, Governance and Diplomacy: The Urban Link, Routledge, Toly, New York, DOI: 10.4324/9780203073810.

Acuto M., Rayner S. (2016), City networks: breaking gridlocks or forging (new) lock-ins?, "International Affairs", 92(5): 1147-1166.

Acuto M., Morissette M., Tsouros A. (2017), City diplomacy: Towards more strategic networking? Learning with WHO healthy cities, "Global Policy", 8(1): 14-22.

Adger W. N., Jordan A. (eds.) (2009), Governing sustainability, Cambridge University Press.

Andonova L. B., Betsill M. M., Bulkeley H. (2009), Transnational climate governance, "Global environmental politics", 9(2): 52-73.

Aldecoa F., Keating M. (eds.) (1999), Paradiplomacy in Action: The Foreign Relations of Subnational Governments, Frank Cass, London.

Alger C. F. (1984), Bridging the Micro and the Macro in International Relations Research, "Alternatives", 10(3): 319-344, https://doi.org/10.1177/030437548401000301.

Amiri S., Sevin E. (2020), City Diplomacy: Current Trends and Future Prospects, Palgrave Macmillan, DOI: 10.1007/978-3-030-45615-3.

ARUP report (2011), Climate Action in Megacities: C40 Cities Baseline and Opportunities (Version 1.0) C40 Climate Leadership Group and ARUP, http://www.arup.com/News/2011_06_ June/01_Jun_11_C40_Climate_Action_Megacities_Sao_Paulo.aspx (21.10.2020).

Bäckstrand K. (2008), Accountability of networked climate governance: The rise of transnational climate partnerships, "Global environmental politics", 8(3): 74-102.

Bäckstrand K., Lövbrand E. (eds.) (2015), Research handbook on climate governance, Edward Elgar Publishing.

Bäckstrand K., Kuyper J. W., Linnér B.-O., Lövbrand E. (2017), Non-state actors in global climate governance: from Copenhagen to Paris and beyond, "Environmental Politics", 26 (4): 561-579, DOI: 10.1080/09644016.2017.1327485. 
Barber B. R. (2013), If Mayors Ruled the World: Dysfunctional Nations, Rising Cities, Yale University Press.

Betsill M., Bulkeley H. (2006), Cities and the Multilevel Governance of Global Climate Change, "Global Governance", 12(2): 141-159, www.jstor.org/stable/27800607.

Bouteligier S. (2013), Cities, Networks, and Global Environmental Governance: Spaces of Innovation, Places of Leadership, Routledge, New York.

Bueger C., Gadinger F. (2018), International Practice Theory, Palgrave Macmillan, Basingstoke.

C40 Cities (2018), A Year of Dazzling City Climate Leadership, 5.12.2018, https://www.thechicagocouncil.org/blog/global-insight/multilateral-window-city-diplomacy (15.3.2021).

Castells M. (2005), Global governance and global politics, "PS: Political Science and Politics", 38(1): 9-16.

Cornago N. (2010), On the Normalization of Sub-State Diplomacy, in: Regional Sub-state Diplomacy Today, (ed.) D. Criekemans, Leiden-Boston.

Criekemans D. (Hg.) (2010), Regional Sub-state Diplomacy Today, Leiden-Boston.

Curtis S. (ed.) (2014), The Power of Cities in International Relations, Routledge, New York, https:// doi.org/10.4324/9781315851495.

Curtis S. (2016), Cities and global governance: State failure or a new global order?, "Millennium", 44(3): 455-477.

Dryzek J. S. (2017), The Meanings of Life for Non-state Actors in Climate Politics, "Environmental Politics", 26(4): 789-799, DOI:10.1080/09644016.2017.1321724.

Giddens A. (2000), Runaway world: how globalization is reshaping our lives, Routledge, New York.

Graham E. (2021), Global Electricity Review 2021, EMBER, https://ember-climate.org/global-electricity-review-2021/g20-profiles/united-states/ (23.6.2021).

Hale T. (2018), The role of sub-state and non-state actors in international climate processes, Chatham House, Londres.

Hickmann T. (2015), Rethinking authority in global climate governance: How transnational climate initiatives relate to the international climate regime, Routledge.

Hocking B. (1993), Localizing Foreign Policy: Non-central Governments and Multilayered Diplomacy, St. Martin's Press, New York, N.Y..

Hooghe L. (2001), The European Commission and the Integration of Europe: Images of Governance, Cambridge University Press.

Jordan A. J., Huitema D., Hildén M., Van Asselt H., Rayner T. J., Schoenefeld J. J., ... Boasson E. L. (2015), Emergence of polycentric climate governance and its future prospects, "Nature Climate Change", 5(11): 977-982.

Kaiser R. (2003), Paradiplomacy and Multilevel Governance in Europe and North America: Subnational Governments in International Arenas, "Participation", vol. 27.

Keating M. (1999), Regions and International Affairs: Motives, Opportunities and Strategies, "Regional \& Federal Studies", Vol. 9, No. 1: 1-16.

Keohane R. O., Nye J. S. (1974), Transgovernmental Relations and International Organizations, "World Politics", Vol. 27, No. 1: 39-62.

Kern K. (2019), Cities as leaders in EU multilevel climate governance: Embedded upscaling of local experiments in Europe, "Environmental Politics", 28(1): 125-145.

Kirby A., Marston S., Seasholes K. (1995), World cities and global communities: the municipal foreign policy movement and new roles for cities, World cities in a world-system: 267-279.

Kuznetsov A. S. (2015), Theory and Practice of Paradiplomacy: Subnational Governments in International Affairs, Routledge, New York. 
Kuyper J. W., Linnér B. O., Schroeder H. (2018), Non-state actors in hybrid global climate governance: justice, legitimacy, and effectiveness in a post-Paris era, "Wiley Interdisciplinary Reviews: Climate Change", 9(1): e497.

Lecours A. (2002), Paradiplomacy: Reflections on the Foreign Policy and International Relations of Regions, "International Negotiation", Vol. 7, No. 1.

Lee T. (2013), Global Cities and Transnational Climate Change Networks, "Global Environmental Politics", 13:1: 108-127.

Leffel B. (2017), City Diplomacy in the Age of Brexit \& Trump, "Public Diplomacy Magazine", (18): 9-14.

Leffel B. (2018), Animus of the Underling: Theorizing City Diplomacy in a World Society, "The Hague Journal of Diplomacy”, 13(4): 502-522. DOI: https://doi.org/10.1163/1871191X-13040025.

McMillan S. L. (2008), Subnational foreign policy actors: How and why governors participate in US foreign policy, "Foreign Policy Analysis", 4(3): 227-253.

Newell P., Pattberg P., Schroeder H. (2012), Multiactor governance and the environment, "Annual Review of Environment and Resources", 37.

Oosterlynck S., Bassens D., Beeckmans L., Derudder B. (2019), An urban studies take on global urban political agency, The City as a Global Political Actor: 1-21.

Pouliot V., Cornut J. (2015), Practice theory and the study of diplomacy: A research agenda, "Cooperation and conflict", 50(3): 297-315.

Rapoport E., Acuto M., Grcheva L. (2019), Setting Priorities. Leading Cities, UCL Press, 2019-3-6: $59-75$.

Sassen S. (2001, The Global City: New York, London, Tokyo, Princeton University Press, Princeton, N.J..

Sassen S. (2004), Local actors in global politics, "Current sociology”, 52(4): 649-670.

Shuman M. (1986), Why Cities Are Entering International Affairs: An Overview, "Bulletin of Municipal Foreign Policy", Vol. 1, No. 1 (Winter, 1986-87).

Shuman M. (1988), Support Your Local State Department, "Bulletin of Municipal Foreign Policy", Vol. 2, No. 2 (Spring, 1988).

Tavares R. (2016), Paradiplomacy. Cities and States as Global Players, Oxford University Press, Oxford.

Utomo A. B. (2019), Reimagining City Identities in Globalisation: A Constructivist Study on City Paradiplomacy, The Annual Convention on the Global South.

van der Pluijm R., Melissen J. (2007), City Diplomacy: The Expanding Role of Cities in International Politics, Netherlands Intitute of International Relations Clingendael.

Wang J. (2006), Localising public diplomacy: The role of sub-national actors in nation branding, "Place Branding", 2(1): 32-42.

\begin{abstract}
One of the effects of globalization is the increasing number of transnational ties that central governments not only ceased to control but also ceased to participate in; therefore, in recent decades, cities have been increasingly motivated to respond to international issues and initiate various contacts with foreign economic, cultural, and political centres. This article examines practices of city diplomacy in light of the current climate crisis. Albeit cities could be in conflict with their central government, they are executing the global climate agenda. Nonetheless, how do we frame cities' autonomous activities in the global governance agenda?
\end{abstract}


The article seeks to determine whether the framework of hybrid multilateralism is the niche for cities to assume the role of the central government in defending common global values such as preservation of the environment when the state fails to do so. Based on a dataset consisting of various subnational initiatives responding to climate change, we suggest a remarkable growth in the pledges to the international climate agreements' commitments involving many subnational actors. Through these pledges, cities enter the international negotiations with various partners under hybrid policy architecture.

Cities hold an enormous potential to influence the global conversation on climate change agenda. Furthermore, we conclude that cities are taking on the states' role in global issues when they identify the inadequacy of the central governments' action. Their conflict position forces them to carry out autonomous activities and fosters the new phenomenon of hybrid multilateralism.

Keywords: hybrid multilateralism, city diplomacy, global governance, climate change

\section{MIASTA W KIERUNKU GLOBALNEGO ZARZĄDZANIA KLIMATEM: JAK PRAKTYKI DYPLOMACJI MIEJSKIEJ WSPIERAJĄ MULTILATERALIZM HYBRYDOWY}

\section{STRESZCZENIE}

Jednym ze skutków globalizacji jest rosnąca liczba powiązań transnarodowych, w których rządy centralne nie tylko przestały je kontrolować, ale i w których przestały uczestniczyć. W związku z tym w ostatnich dziesięcioleciach miasta były coraz bardziej zmotywowane do reagowania na problemy międzynarodowe i inicjowania różnorodnych kontaktów z zagranicznymi ośrodkami gospodarczymi, kulturalnymi i politycznymi. W artykule przyjrzymy się praktykom dyplomacji miejskiej w świetle obecnego kryzysu klimatycznego. Chociaż miasta mogą być w konflikcie z rządem centralnym, realizują globalną agendę klimatyczną. Niemniej jednak powstaje pytanie, w jaki sposób umieścimy autonomiczne działania miast w agendzie globalnego zarządzania?

Artykuł ma na celu ustalenie, czy ramy multilateralizmu hybrydowego są niszą dla miast, które mogą przejąć rolę rządu centralnego w obronie wspólnych globalnych wartości, takich jak ochrona środowiska, gdy nie robi tego państwo. Opierając się na zbiorze danych składających się z różnych lokalnych inicjatyw reagujących na zmiany klimatu, sugerujemy znaczny wzrost zobowiązań w zakresie zobowiązań międzynarodowych porozumień klimatycznych z udziałem wielu podmiotów na szczeblu niższym niż krajowy. Dzięki tym zobowiązaniom miasta przystępują do międzynarodowych negocjacji z różnymi partnerami w ramach hybrydowej architektury polityki.

Miasta mają ogromny potencjał wpływania na globalną dyskusję na temat agendy zmian klimatycznych. Ponadto dochodzimy do wniosku, że miasta przejmują rolę państw w kwestiach globalnych, gdy stwierdzają nieadekwatność działań rządów centralnych. Konfliktowa pozycja zmusza je do prowadzenia autonomicznych działań i sprzyja nowemu zjawisku hybrydowego multilateralizmu.

Słowa kluczowe: multilateralizm hybrydowy, dyplomacja miejska, globalne zarządzanie, zmiana klimatu 
